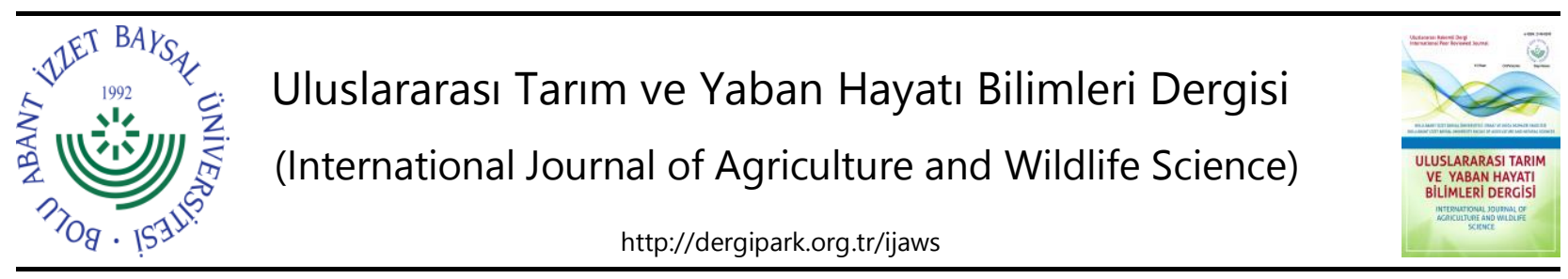

Araştırma Makalesi

\title{
Domates (Lycopersicon esculentum Mill.) Meristemlerinin In Vitro Gelişimi Üzerine Bazı Bitki Büyüme Düzenleyicilerinin Etkisi ${ }^{* *}$
}

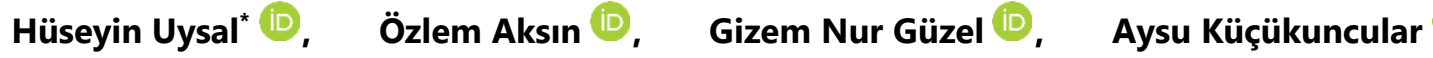

Aydın Adnan Menderes Üniversitesi, Ziraat Fakültesi, Tarımsal Biyoteknoloji Bölümü, Aydın

Geliş tarihi (Received): 13.02.2021 Kabul tarihi (Accepted): 15.03.2021

\begin{abstract}
Anahtar kelimeler:
Domates, Lycopersicon

esculentum, meristem

kültürü, oksin, sitokinin

*Sorumlu yazar

huseyin.uysal@adu.edu.tr

Özet. Bu çalışma in vitro koşullarda yetiştirilen domates bitkilerinden elde edilen meristemlerin farklı konsantrasyonlarda BAP (6-benzil amino pürin- sitokinin hormonu) ve IAA (Indol-3-asetik asit- oksin hormonu) içeren besi ortamlarındaki gelişimini araştırmak amacıyla gerçekleştirilmiştir. Araştırmada temel besi ortamı olarak MS (Sigma Aldrich, Katalok No:M5519) besi ortamı kullanılmış olup bu ortama $0.1,0.5$ ve $1.0 \mathrm{mg} \mathrm{l}^{-1}$ oranlarında ayrı ayrı BAP ve IAA ilave edilmiş yine kullanılan temel besi ortamına $0.1 \mathrm{mg} \mathrm{l}^{-1} \mathrm{BAP}+0.5 \mathrm{mg} \mathrm{l}^{-1}$ IAA ve $0.5 \mathrm{mg} \mathrm{l}^{-1} \mathrm{BAP}+0.1 \mathrm{mg} \mathrm{l}^{-1}$ IAA oranlarında sitokinin ve oksin hormonları birlikte ilave edilmiştir. Araştırma sonucunda tam bir bitki oluşumu bakımından en yüksek başarı oranı \%61.11 ile $0.5 \mathrm{mg} \mathrm{l}^{-1} \mathrm{BAP}+0.1 \mathrm{mg} \mathrm{^{-1 } | \mathrm { AA }}$ içeren besi ortamından elde edilmiştir. Hiçbir hormon kullanılmayan yalın besi ortamı toplam direk rejenerasyon (sürgün, kök, sürgün + kök oluşumu) bakımından en iyi sonucu verirken (\%100), kallus oluşumu bakımından ise $0.5 \mathrm{mg} \mathrm{l}^{-1}$ BAP $+0.1 \mathrm{mg} \mathrm{l}^{-1}$ IAA içeren ortam en iyi sonucu (\%100) vermiştir. Yine kalluslardan bitki rejenerasyonu bakımından en iyi sonucu (\%340) $0.5 \mathrm{mg} \mathrm{l}^{-1} \mathrm{BAP}+$ $0.1 \mathrm{mg} \mathrm{l}^{-1}$ IAA içeren MS besi ortamı ortaya koymuştur. Araştırmanın genel sonucu değerlendirildiğinde yüksek konsantrasyonda kullanılan BAP veya IAA hormonlarının domates meristemlerinde kallus oluşumunu teşvik ettiği saptanmıştır.
\end{abstract}

\section{Effect of Some Plant Growth Regulators on In Vitro Regeneration of Meristems of Tomato (Lycopersicon esculentum Mill.)}

\section{Keywords:}

Tomato, Lycopersicon esculentum, meristem culture, auxin, cytokinin
Abstract. This study was carried out to investigate the development of meristems obtained from tomato plants grown in vitro conditions in medium containing different concentrations of BAP (6benzyl amino purine-cytokinin hormone) and IAA (Indole-3-acetic acid-auxin hormone). MS (Sigma Aldrich, Catalog No: M5519) medium was used as the main media and BAP and IAA were added separately at the rates of $0.1,0.5$ and $1.0 \mathrm{mg} \mathrm{l}^{-1}$ in this medium, and also cytokinin and auxin hormones were added together as concentrations of $0.5 \mathrm{mg} \mathrm{l}^{-1} \mathrm{BAP}+0.1 \mathrm{mg} \mathrm{l}^{-1} \mathrm{IAA}$ and 0.1 $\mathrm{mg} \mathrm{l}^{-1} \mathrm{BAP}+0.5 \mathrm{mg} \mathrm{l}^{-1} \mathrm{IAA}$ in this medium in the research. As a result of the research, the highest success rate in terms of complete plant formation rate as $61.11 \%$ obtained from the medium containing $0.5 \mathrm{mg} \mathrm{I}-1 \mathrm{BAP}+0.1 \mathrm{mg} \mathrm{I}-1 \mathrm{IAA}$. The nutrient medium without any hormones gave the best results in terms of total direct regeneration (shoot, root and shoot + root) rate (100\%), while the medium containing $0.5 \mathrm{mg} \mathrm{l}^{-1}$ BAP $+0.1 \mathrm{mg} \mathrm{l}^{-1}$ IAA gave the best result $(100 \%)$ in terms of callus formation. MS medium containing $0.5 \mathrm{mg} \mathrm{l}^{-1} \mathrm{BAP}+0.1 \mathrm{mg} \mathrm{l}^{-1}$ IAA again showed the best result $(340 \%)$ in terms of plant regeneration from the calluses. When the general result of the study was evaluated, it was determined that BAP or IAA hormones used in high concentrations encouraged callus formation in tomato meristems. 


\section{GíRiş}

Ülkemiz birçok sebze türü için önemli bir çeşitlilik alanına sahiptir. Anadolu topraklarının pek çok medeniyete ev sahipliği yapmış olması ve sahip olduğu ekolojik çeşitlilik nedeniyle hemen hemen bütün bitki türlerinde olduğu gibi domateste de uzun yıllar içerisinde varyasyonun ortaya çıkmasını sağlamış ve değişik kaynaklardan ülkeye giriş yapan materyallerin de bulundukları yörelerde yetiştirilmesiyle özellikleri birbirinden farklı yöresel domates çeşitleri oluşmuştur. Anadolu toprakları, birçok bitki türünün anavatanı olup, günümüzde de kültüre alınmış ve tüm dünyada ekonomik öneme sahip sebze türleri bakımından hem anavatan hem de yetiştirme alanı olarak stratejik bir önem taşımaktadır (Oğuz, 2010).

Domates (Lycopersicon esculentum Mill.), patlıcangiller (Solanaceae) familyasından, $2 \mathrm{n}=24$ adet kromozoma sahip bir kültür bitkisidir (Spooner ve ark., 2005; Zengin, 2016). Anavatanı, Peru, Ekvator, Galapagus Adaları ve Şili'nin dağlık bölgeleridir. Domates, ilk defa Meksikalılar tarafından kültüre alınmış ve buradan dünyaya yayılmıştır (Zengin, 2016). Ülkemizde domates yetiştiriciliği, 1900'lü yılların başlarında Adana'da başlamış ve son 40 yıl içerisinden günümüze kadar hem ıslah hem de yetiştiricilik bakımından oldukça hızlı yayılmıştır. Türkiye'de 2019 yılı verilerine göre toplam 31089644 ton olan sebze üretiminin 12841990 tonluk payı domates üretimine ait olup, domates diğer sebzeler arasında \%41.3'lük pay ile birinci sırada yer almıştır (TÜiK, 2019).

Domates kullanım alanları çok geniş olan meyvesi yenen sebzeler grubunda yer alan bir bitkidir. Yaş meyve olarak meyvesinin hemen hemen her mevsimde tüketilmesinin yanı sıra konserve, ketçap, domates suyu, sos, salça gibi farklı şekillerde tüketilebilmektedir (Oğuz, 2010).

Domateste virüs kaynaklı hastalıklar üretimde verim ve kaliteyi düşüren hastalıkların başında gelmektedir (Öztunç, 2010; Çevik ve Akçura, 2011; Sakallı, 2018). Günümüzde bitki viral hastalıklarılla mücadelede etkin bir yöntem bulunmamaktadır. Virüs hastalıkları gerek üretim materyali ve gerekse yetiştiriciliğin yapıldığı toprak vasıtasıyla yayılmaktadır. Bu nedenle virüs ihtiva etmeyen veya viral hastalıklara dayanıklı üretim materyalinin kullanılması büyük önem arz etmektedir. Biyoteknolojik yöntemlerden olan meristem kültürü aracılığıyla geliştirilen fideler virüs ihtiva etmemekte olup bu bakımdan büyük bir avantaj sağlamaktadır.

Biyoteknolojik yöntemler; l) döneme bağlı kalmaksızın arzu edilen genotiplerin çok kısa sürede çoğaltılmaları, ii) klasik yöntemlerle başarılamayan cinsler ve türler arası melezlerin elde edilmesine olanak sağlayarak, cinsler ve türler arası gen transferleri, $ı$ ) çok kısa sürede homozigot hatların elde edilmesi ve $ı$ ) üretimde temiz üretim materyali sağlanması gibi bitkisel üretim ve bitki ıslahına çok önemli katkılar saylayan teknikleri içermektedir. İn vtiro tekniklerden olan meristem kültürü; bitkilerin büyüme konileri veya büyüme konisi yanında birkaç yaprak primordiasının steril koşullarda suni besi ortamında kültüre edilerek bunlardan yeni bitkiler elde edilmesini kapsayan bir tekniktir (Hatipoğlu, 2012).

İn vitro çalışmalarda direk ve indirek olmak üzere 2 tip bitki rejenerasyonu bulunmaktadır. Direk rejenerasyonda kültüre alınan bitki eksplantı herhangi bir kallus fazı olmaksızın direk sürgün, kök veya hem sürgün hem de kök oluşturabilmektedir. Oluşan rejenerasyon sadece kök veya sadece sürgün şeklinde ise bu olaya orgonagenesis adı verilirken, kök ve sürgün içeren tam bir bitki oluşumu söz konusu ise bu olaya da embriyogenesis adı verilmektedir. Bitkilerin genetik yapılarının korunmasının önemli olduğu çalışmalarda direk rejenerasyon protokolleri ön plana çıkmaktadır. Bitkilerde en az varyasyonların görüldüğü çalışmalar meristematik dokuların kullanıldığı rejenerasyon çalışmalarıdır (Gerszberg ve ark., 2015). Ayrıca meristem kültürü; başta virüsler olmak üzere hastalıklardan ari bitki geliştirilmesinde kullanılan çok önemli bir tekniktir. Bu teknik sayesinde virüsten ari üretim materyalleri elde edilebilmek ve virüsün neden olduğu ekonomik kayıplardan önemli ölçüde kaçınılabilmektedir (Hatipoğlu, 2012).

Bu çalışma; Domates bitkisi tohumlarının steril koşullarda çimlenmesiyle elde edilen bitkilerin meristemlerinin kültürleri yapılarak en ideal BAP (6-benzil amino pürin- sitokinin) ve İAA (İndol-3-asetik asit- oksin) konsantrasyonunu belirlemek amacıyla yürütülmüştür.

\section{MATERYAL VE METOT}

Bu araştırma Aydın Adnan Menderes Üniversitesi (ADÜ), Ziraat Fakültesi, Tarımsal Biyoteknoloji Bölümü Doku Kültürü Laboratuvarında ve Ziraat Fakültesi seralarında yürütülmüştür.

Araştırmada Antalya ili, Gazipaşa ilçesi, Doğanca köyündeki üreticilerden temin edilmiş olan yerel domates popülasyonuna ait in vitro koşullarda çimlendirilmiş tohumların fidelerinden elde edilen meristemler kullanılmıştır.

Yüzey sterilizasyonu için tohumlar, öncelikle \%70'lik etil alkol ile 10-15 sn muamele edilmiştir. Daha sonra \%10'luk çamaşır suyu (ACE) ile $10 \mathrm{dk}$ muamele edildikten sonra Biyogüvenlik kabini içerisinde steril su ile 3-4 
kez durulanmış ve ekimi gerçekleştirilmiştir. Araştırmaya konu domates tohumları in vitro koşullarda hormon intiva etmeyen yalın MS (Sigma Aldrich, Katalok No: M5519) besi ortamında çimlendirilerek yetiştirilmiştir (Çizelge 1). Kullanım periyodunu yeterli zamana yaymak için bitkiler 5 set halinde belirli aralıklar ile ekilmiştir. Her bir set için, kapakları delinerek sünger yerleştirilmiş olan 1 litrelik steril konserve kavanozlarına, her kavanozda 8 tohum olacak şekilde 10 adet kavanoza ekim gerçekleştirilmiştir. Bitkilerin gelişimi $25^{\circ} \mathrm{C}$ sıcaklık ve 8 saat karanlık 16 saat aydınlık fotoperiyoda sahip iklimlendirme odasında yetiştirilmiştir. Ekim sonrası bitkiler 6 $7 \mathrm{~cm}$ boya ulaştıklarında biyogüvenlik kabini içerisinde meristemleri alınıp magenta kapları içerisine hazırlanmış Çizelge 2'de verilen 9 farklı besi ortamında kültüre alınmıştır.

Çizelge 1. Çalışma kapsamında kullanılan MS (Sigma Aldrich, Katalok No: M5519) besi ortamının içeriği. Table 1. Content of MS (Sigma Aldrich, Catalog No: M5519) medium used in the study.

\begin{tabular}{|c|c|}
\hline Kimyasal Madde & Miktar (mg l-1) \\
\hline $\mathrm{KNO}_{3}$ & 1900 \\
\hline $\mathrm{CaCl}_{2} \cdot \mathrm{H}_{2} \mathrm{O}$ & 332.2 \\
\hline $\mathrm{NH}_{4} \mathrm{NO}_{3}$ & 1650 \\
\hline $\mathrm{MgSO}_{4} \cdot 7 \mathrm{H}_{2} \mathrm{O}$ & 180.7 \\
\hline $\mathrm{KH}_{2} \mathrm{PO}_{4}$ & 170 \\
\hline $\mathrm{Na}_{2}-\mathrm{EDTA}$ & 37.25 \\
\hline $\mathrm{FeSO}_{4} .7 \mathrm{H}_{2} \mathrm{O}$ & 27.85 \\
\hline $\mathrm{H}_{3} \mathrm{BO}_{3}$ & 6.2 \\
\hline $\mathrm{MnSO}_{4} \cdot \mathrm{H}_{2} \mathrm{O}$ & 16.9 \\
\hline $\mathrm{ZnSO}_{4} .7 \mathrm{H}_{2} \mathrm{O}$ & 8.6 \\
\hline $\mathrm{KI}$ & 0.83 \\
\hline $\mathrm{Na}_{2} \mathrm{MoO}_{4} \cdot \mathrm{H}_{2} \mathrm{O}$ & 0.25 \\
\hline $\mathrm{CuSO}_{4} \cdot 5 \mathrm{H}_{2} \mathrm{O}$ & 0.025 \\
\hline $\mathrm{CoCl}_{2} \cdot 6 \mathrm{H}_{2} \mathrm{O}$ & 0.025 \\
\hline Glycin & 2.0 \\
\hline Myo-Inostol & 100 \\
\hline Nicotinic asit & 0.5 \\
\hline Pyrodoxine-HCl & 0.5 \\
\hline Thiamin $\mathrm{HCl}$ & 0.1 \\
\hline Sukroz* & 30000 \\
\hline Agar* & 7000 \\
\hline $\mathrm{PH}$ & 5.8 \\
\hline
\end{tabular}

* Hazır olarak alınan besi ortamı içerisinde yer almamakta olup hazırlık aşamasında ayrıca ilave edilmiştir.

Çizelge 2. Araştırma kapsamında kullanılan besi ortamına ilave edilen BAP ve IAA konsantrasyonları. Table 2. BAP and IAA concentrations added to the medium used in the research.

\begin{tabular}{lll}
\hline Besi Ortamı No & BAP $\left(\mathbf{m g ~ l}^{-1}\right)$ & IAA $\left(\mathbf{m g ~ l}^{-1}\right)$ \\
\hline MS1 & - & - \\
MS2 & 0.1 & - \\
MS3 & 0.5 & - \\
MS4 & 1.0 & - \\
MS5 & - & 0.1 \\
MS6 & - & 0.5 \\
MS7 & - & 1.0 \\
MS8 & 0.1 & 0.5 \\
MS9 & 0.5 & 0.1 \\
\hline
\end{tabular}


Araştırma kapsamında kültürü alınan meristemlerde elde edilen tam bitki sayıları, direk rejenere sürgün ve kök sayıları, elde edilen kallus sayıları, kalluslardan elde edilen sürgün sayıları gün aşırı yapılan kontrollerle belirlenerek kaydedilmiştir.

Araştırma sonucunda elde edilen verilerin minimum maksimum ve ortalama değerlerinin hesaplanmasında ve grafiklerin çizilmesinde Microsoft Excell paket programından yararlanılmıştır.

\section{BULGULAR VE TARTIŞMA}

Araştırma kapsamında kültüre alınan domates meristemlerinin oluşturmuş olduğu direk sürgün, kök ve sürgün + kök oluşturma sayıları ve başarı oranlarına ilişkin veriler Çizelge 3 'te verilmiştir.

Çizelge 3. Araştırma kapsamında kültüre alınan domates meristemlerinden elde edilen direk sürgün, kök ve tam bitki oluşum sayıları ve başarı oranlarına (\%) ilişkin veriler.

Table 3. Data on direct shoot, root and complete plant formation numbers and success rates (\%) obtained from tomato meristems cultivated within the scope of the research.

\begin{tabular}{|c|c|c|c|c|c|c|c|}
\hline $\begin{array}{l}\text { Besi } \\
\text { Yeri* }\end{array}$ & $\begin{array}{l}\text { Eksplant } \\
\text { Sayısı } \\
\text { (Adet) }\end{array}$ & $\begin{array}{l}\text { Köksüzz } \\
\text { Sürgün } \\
\text { Oluşturan } \\
\text { (Adet) }\end{array}$ & $\begin{array}{l}\text { Sadece } \\
\text { Kök } \\
\text { Oluşturan } \\
\text { (Adet) }\end{array}$ & $\begin{array}{l}\text { Tam Bitki } \\
\text { Oluşturan } \\
\text { (Adet) }\end{array}$ & $\begin{array}{l}\text { Tam Bitki } \\
\text { Oluşum } \\
\text { Oranı (\%) }\end{array}$ & $\begin{array}{l}\text { Toplam Direk } \\
\text { Rejenerasyon } \\
\text { (Adet) }\end{array}$ & $\begin{array}{l}\text { Direk } \\
\text { Rejenerasyon } \\
\text { Oranı (\%) }\end{array}$ \\
\hline MS1 & 18 & 5 & 3 & 10 & 55.56 & 18 & 100.00 \\
\hline MS2 & 21 & 3 & 0 & 11 & 52.38 & 14 & 66.67 \\
\hline MS3 & 21 & 2 & 0 & 6 & 28.57 & 8 & 38.10 \\
\hline MS4 & 21 & 0 & 0 & 0 & 0.00 & 0 & 0.00 \\
\hline MS5 & 21 & 0 & 0 & 11 & 52.38 & 11 & 52.38 \\
\hline MS6 & 21 & 0 & 13 & 4 & 19.05 & 17 & 80.95 \\
\hline MS7 & 24 & 0 & 6 & 2 & 8.33 & 8 & 33.33 \\
\hline MS8 & 21 & 0 & 0 & 0 & 0.00 & 0 & 0.00 \\
\hline MS9 & 18 & 0 & 0 & 11 & 61.11 & 11 & 61.11 \\
\hline
\end{tabular}

Çizelge 3'ün incelenmesinden de anlaşılacağı gibi araştırmaya konu besi ortamlarında kültüre alınan meristemlerden direk rejenerasyon göstererek sürgün ve kök içeren tam bitki oluşum oranı en yüksek \%61.11 ile $0.5 \mathrm{mg} \mathrm{l}^{-1}$ BAP $+0.1 \mathrm{mg} \mathrm{l}^{-1}$ IAA içeren besi ortamından elde edilmiştir. Bu ortamı \%55.56 başarı oranı ile yalın besi ortamı ve $\% 52.38$ başarı oranı ile $0.1 \mathrm{mg} \mathrm{l}^{-1}$ BAP ve aynı oranda IAA içeren besi ortamları takip etmiştir.

Araştırmaya konu besi ortamları içerisinde toplam direk rejenerasyon bakımından en yüksek başarı \%100 ile herhangi bir hormon içermeyen yalın besi ortamından elde edilmiştir. Yalın ortamda kültüre alınan 18 meristemin 10 adeti köklü bitki oluşturarak tam bitki oluşturmuştur. Geriye kalan 8 adet meristemde ise organogenesis gözlenmiştir. Bunlardan 5 adeti köksüz sürgün oluşturmuş ve 3 adeti ise kök oluşturmuş ama sürgün gelişimini sağlayamamıştır. Yalın besi ortamını ise \%80.95'lik direk rejenerasyon oranı ile $0.5 \mathrm{mg} \mathrm{I}^{-1}$ IAA içeren besi ortamı takip etmiştir. Ancak bu ortamda kültüre alınan 21 meristemden sadece 4 adeti tam bitki haline dönüşmüştür. Geriye kalan 13 ekplant ise sadece kök geliştirmiş ancak sürgün geliştirememiştir. Bu ortamı ise \%66.67'lik başarı oranı ile $0.1 \mathrm{mg} \mathrm{l}^{-1} \mathrm{BAP}$ içeren besi ortamı takip etmiş, bu ortamda ise kültüre alınan 21 meristemin $11^{\prime} i$ tam bitki oluştururken 3 adeti sadece sürgün oluşumu sağlamıştır. $1.0 \mathrm{mg} \mathrm{I}^{-1}$ BAP içeren ve $0.1 \mathrm{mg} \mathrm{l}^{-1} \mathrm{BAP}+0.5 \mathrm{mg} \mathrm{l}^{-1}$ IAA içeren ortamlarda ise direk rejenerasyon gerçekleşmemiştir.

Meristem kültürleri, in vitro çalışmalarda genetik yapının korunması ve direk rejenerasyon çalışmalarında ön plana çıkmaktadır (Ajenifujah-Solebo ve ark. 2012; Namitha ve Negi 2013; Gerszberg ve ark., 2015). Bu çalışmada da yalın ortamda meydana gelen en yüksek bitki rejenerasyonu göstermiştir ki domateste meristematik dokular direk bitki rejenerasyonun protokollerinde kullanılabilecek en iyi eksplant kaynaklarındandır.

Araştırma kapsamında kültüre alınan domates meristemlerinin oluşturmuş olduğu kallus sayıları, kallusların oluşturmuş olduğu sürgün sayıları ve başarı oranlarına ilişkin veriler Çizelge 4 'te verilmiştir.

Çizelge 4'ün incelenmesinden de anlaşılacağı gibi kallus oluşum oranı bakımından en yüksek başarı oranı $\% 100$ ile $0.1 \mathrm{mg} \mathrm{l}^{-1}$ BAP $+0.5 \mathrm{mg} \mathrm{l}^{-1}$ IAA içeren ortamdan elde edilmiştir. Bu ortamda kültüre alınan 21 eksplantın tamamı kallus oluşturmuştur. Bu ortamı \%80.95'lik başarı oranı ile $1.0 \mathrm{mg} \mathrm{I}^{-1}$ BAP içeren ortam takip etmiştir. Burada ise kültüre alınan 21 eksplantın 17'si kallus oluşturmuştur. İncelenen besi ortamları içerisinde 
yalın ortamda, $0.1 \mathrm{mg} \mathrm{l}^{-1}$ IAA içeren ve $0.5 \mathrm{mg} \mathrm{l}^{-1}$ IAA içeren ortamlarda ise herhangi bir kallus oluşumuna rastlanmamıştır.

Çizelge 4. Araştırma kapsamında kültüre alınan domates meristemlerinin oluşturmuş olduğu kallus sayıları, kallusların oluşturmuş olduğu sürgün sayıları ve başarı oranlarına (\%) ilişkin veriler.

Table 4. Data on the number of callus formed by tomato meristems cultivated within the scope of the study, the number of shoots created by the callus and the success rates (\%).

\begin{tabular}{|c|c|c|c|c|c|}
\hline Besi Yeri* & $\begin{array}{l}\text { Eksplant } \\
\text { Sayısı (Adet) }\end{array}$ & $\begin{array}{l}\text { Kallus Oluşturan } \\
\text { (Adet) }\end{array}$ & $\begin{array}{l}\text { Kallustan Sürgün } \\
\text { Oluşumu (Adet) }\end{array}$ & $\begin{array}{l}\text { Kallus Oluşum } \\
\text { Oranı (\%) }\end{array}$ & $\begin{array}{l}\text { Kallustan Sürgün } \\
\text { Oluşum Oranı (\%) }\end{array}$ \\
\hline MS1 & 18 & 0 & 0 & 0.00 & 0.00 \\
\hline MS2 & 21 & 6 & 18 & 28.57 & 300.00 \\
\hline MS3 & 21 & 12 & 24 & 57.14 & 200.00 \\
\hline MS4 & 21 & 17 & 38 & 80.95 & 223.53 \\
\hline MS5 & 21 & 0 & 0 & 0.00 & 0.00 \\
\hline MS6 & 21 & 0 & 0 & 0.00 & 0.00 \\
\hline MS7 & 24 & 10 & 4 & 41.67 & 40.00 \\
\hline MS8 & 21 & 21 & 62 & 100.00 & 295.24 \\
\hline MS9 & 18 & 5 & 17 & 27.78 & 340.00 \\
\hline
\end{tabular}

Elde edilen kallusların bitki oluşum oranları incelendiğinde en yüksek başarı oranı \%340 ile $0.5 \mathrm{mg} \mathrm{l}^{-1}$ BAP + $0.1 \mathrm{mg} \mathrm{l}^{-1}$ IAA içeren ortamdan elde edilmiştir. Bu ortamdan elde edilen 5 adet kallustan toplam 17 adet sürgün gelişimi sağlanmıştır. Kallustan sürgün oluşumu bakımından bu ortamı \%300'lük başarı oranı ile $0.1 \mathrm{mg} \mathrm{I}^{-1}$ BAP içeren ortam takip etmiştir. Kallus elde edilen ortamlar içerisinde en düşük sürgün rejenerasyonu ise \%40 ile 1.0 $\mathrm{mg} \mathrm{l}^{-1}$ IAA içeren ortamda tespit edilmiştir.

Araştırma kapsamında kültüre alınan domates meristemlerinden elde edilen genel başarı oranlarına ilişkin veriler Çizelge $5^{\prime}$ te verilmiştir. Kültüre alınan meristemlerin besi ortamlarına göre direk rejenerasyon, kallus oluşum ve genel başarı oranlarına ilişkin verilerin grafiksel gösterimi Şekil 1'de verilmiştir.

Çizelge 5. Araştırma kapsamında kültüre alınan domates meristemlerinden elde edilen genel başarı oranlarına ilişkin veriler. Table 5. Data on the general success rates obtained from tomato meristems cultivated within the scope of the research.

\begin{tabular}{llll}
\hline Besi Yeri* & Eksplant Sayısı (Adet) & Genel Toplam Rejenersyon & Genel Başarı Oranı (\%) \\
\hline MS1 & 18 & 18 & 100.00 \\
MS2 & 21 & 20 & 95.24 \\
MS3 & 21 & 20 & 95.24 \\
MS4 & 21 & 17 & 80.95 \\
MS5 & 21 & 11 & 52.38 \\
MS6 & 21 & 17 & 80.95 \\
MS7 & 24 & 18 & 75.00 \\
MS8 & 21 & 21 & 100.00 \\
MS9 & 18 & 16 & 88.89 \\
\hline
\end{tabular}

* MS1: Yalın; MS2:0.1 $\mathrm{mg} \mathrm{l}^{-1}$ BAP; MS3: $0.5 \mathrm{mg} \mathrm{l}^{-1}$ BAP; MS4: $1.0 \mathrm{mg} \mathrm{l}^{-1}$ BAP; MS5:0.1 $\mathrm{mg} \mathrm{l}^{-1}$ IAA; MS6:0.5 mg l-1 IAA; MS7:1.0 mg l-1 IAA; MS8:0.1 mg l-1 BAP + $0.5 \mathrm{mg} \mathrm{l}^{-1}$ IAA; MS9:0.5 mg l-1 BAP + $0.1 \mathrm{mg} \mathrm{l}^{-1}$ IAA.

Çizelge 5 ve Şekil 1'in incelenmesinden de anlaşılacağı gibi araştırmaya konu besi ortamlarından elde edilen genel rejenerasyon oranları incelendiğinde yalın ortam ve $0.5 \mathrm{mg} \mathrm{l}^{-1}$ BAP $+0.1 \mathrm{mg} \mathrm{l}^{-1}$ IAA içeren ortam \%100 oranında rejenerasyon sağlamış bunu \%95.24'lük başarı oranı ile $0.1 \mathrm{mg} \mathrm{l}^{-1} \mathrm{ve} 0.5 \mathrm{mg} \mathrm{l}^{-1}$ BAP içeren ortamlar takip etmiştir. En düşük rejenerasyon ise $\% 52.38$ ile $0.1 \mathrm{mg} \mathrm{l}^{-1}$ IAA içeren ortamdan elde edilmiştir. Şekil 2'de tam bitki oluşumu, kalluslardan bitki oluşumu ve yalnız kök oluşumuna ilişkin resimler yer almaktadır.

Domates üzerine yapılan farklı çalışmalar göstermiştir ki, organogenesis yoluyla gerçekleştirilen bitki rejenerasyonu; genotip, besi ortamı, eksplant kaynakları, eksplant yaşı, ortam bileşimi ve çevresel koşullar gibi çeşitli faktörlerden etkilenmektedir (Devi ve ark., 2008; Chaudhry ve ark., 2010; Ajenifujah-Solebo ve ark., 2012; Al-Remi ve ark., 2018). Bu çalışmada tek bir genotip kullanılmış olup farklı konsantrasyonda hormon içeren besi ortamlarında domatesin rejenerasyon yeteneğinin belirlenmesi amaçlanmıştır. Bitki doku kültürlerinde besi ortamının bileşimi başarıyı etkileyen en önemli faktörlerin başında gelmektedir. Farklı tipteki eksplantlardan domates sürgünü rejenerasyonu ortam koşullarının değiştirilmesi yoluyla başarılabilmiştir. Bunun da ötesinde 
MS veya B5 gibi kullanılan bazal ortamın tipinin rejenerasyon süreci oranını büyük oranda etkilediği ortaya çıkarılmıştır (Bai ve ark., 2007; Wu ve ark., 2011; Raiola ve ark., 2014; ). Bu çalışmanın sonuçlarınca da teyit edildiği gibi MS besi ortamı domates bitkisinde gerçekleştirilecek in vitro çalışmalar için ideal bir kaynak niteliğindedir.

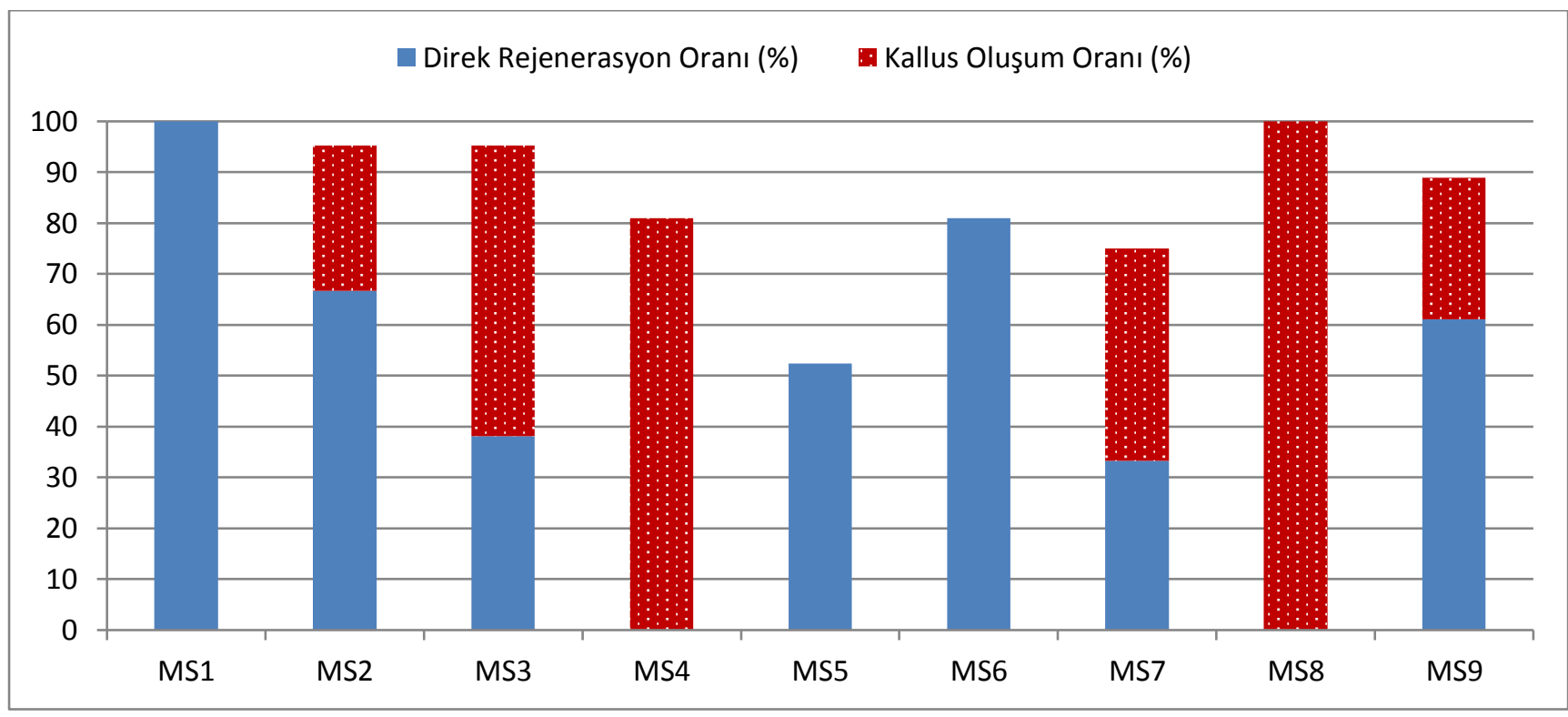

Şekil 1. Kültüre alınan meristemlerin besi ortamlarına göre yüzde olarak direk rejenerasyon, kallus oluşum ve genel başarı oranlarına ilişkin veriler.

Figure 1. Data on direct regeneration, callus formation and general success rates of cultured meristems as a percentage according to the nutrient medium

(MS1: Yalın; MS2:0.1 $\mathrm{mg} \mathrm{l}^{-1}$ BAP; MS3: $0.5 \mathrm{mg} \mathrm{l}^{-1}$ BAP; MS4: $1.0 \mathrm{mg} \mathrm{l}^{-1}$ BAP; MS5:0.1 $\mathrm{mg} \mathrm{l}^{-1}$ IAA; MS6:0.5 mg l-1 IAA; MS7:1.0 mg l-1 IAA; MS8:0.1 mg l-1 BAP + $0.5 \mathrm{mg} \mathrm{l}^{-1}$ IAA; MS9:0.5 $\mathrm{mg} \mathrm{l}^{-1} \mathrm{BAP}+0.1 \mathrm{mg} \mathrm{l}^{-1}$ IAA).
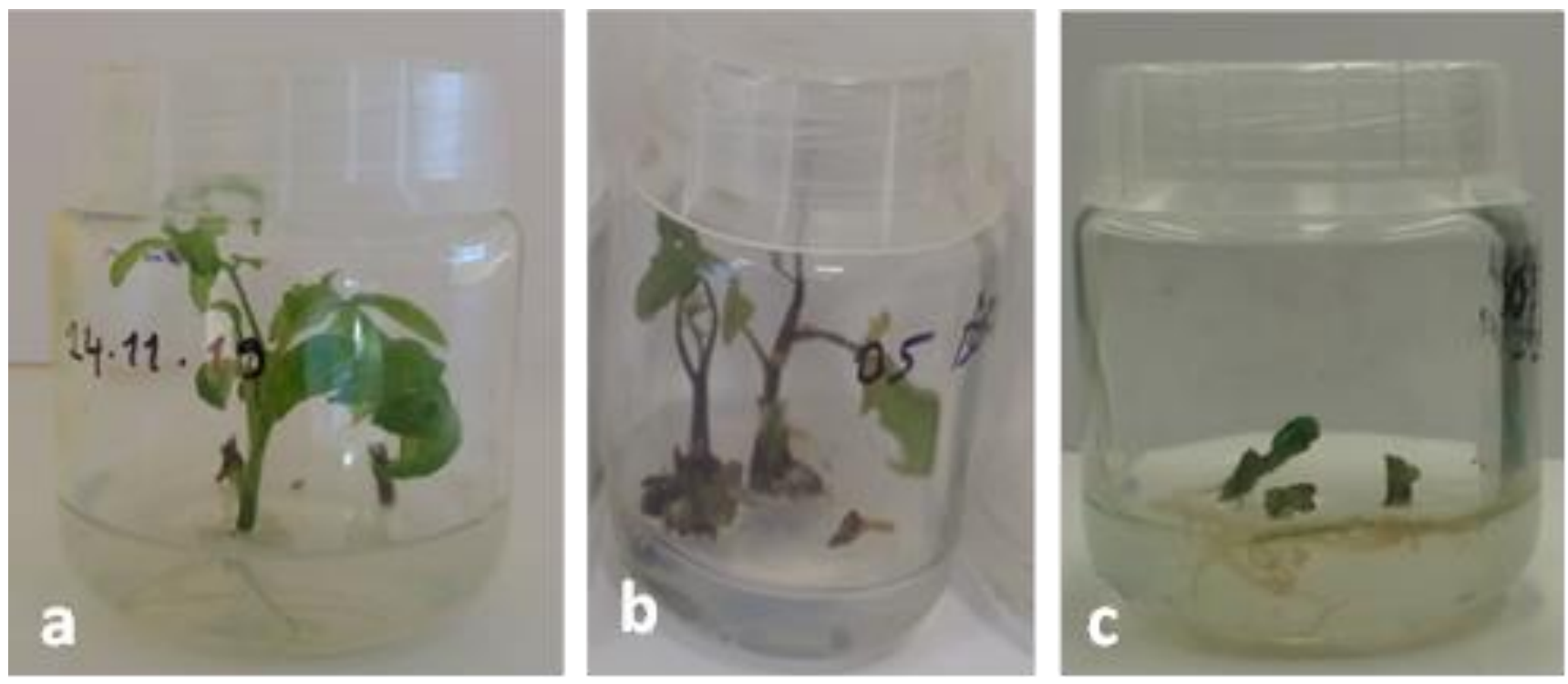

Şekil 2. Tam bitki oluşumu (a), kallusladan sürgün gelişimi (b), sadece kök gelişimi (c).

Figure 2. Complete plant formation (a), shoot growth from calluses (b), root growth only (c).

Bu çalışmada en yüksek direk rejenerasyon oranı hormon içermeyen yalın besi ortamından elde edilmiştir. Bu durum da göstermiştir ki domates bitkisinin meristem kültüründe in vitro rejenerasyon yeteneği yüksektir. BAP konsantrasyonu arttıkça direk sürgün rejenerasyonunda azalma gözlemlenirken kallus oluşum oranında ise artış gözlemlenmiştir. Benzer olarak başka araştırmacılar tarafından yapılan çalışmalarda da BAP hormonunun konsantrasyonundaki artışa bağlı olarak kallus oluşumunun da arttığı rapor edilmiştir (Balachandar ve Rao, 2004; Devi ve ark., 2008). IAA konsantrasyonundaki artışa bağlı olarak belirli bir noktaya kadar $\left(0.5 \mathrm{mg} \mathrm{l}^{-1}\right)$ direk rejenerasyon oranında artış gözlemlenirken bunun üzerinde miktarlarda kullanılan IAA bitkilerde kallus oluşumunu teşvik etmiştir. BAP ve IAA hormonlarının birlikte kullanımlarında ise IAA oranının yüksek olması kallus uyartımına sebebiyet verirken; BAP konsantrasyonunun yüksek olması nispeten direk orgonagenesisi 
teşvik etmiştir. Yine yapılan çalışmalar göstermiştir ki BAP ve IAA hormonlarının ortamda birlikte bulunması ve özellikle bu iki hormonun eşit miktarlarda ve yüksek konsantrasyonlarda besi ortamına ilave edilmesi kallus oluşumuna sebebiyet vermektedir ve aynı zamanda kalluslardan sürgün rejenerasyonunu da teşvik etmektedir (Devi ve ark., 2008). Bizim çalışmamız da bu sonuçları destekler niteliktedir. Yine bizim çalışmamızdan elde etmiş olduğumuz sonuçlara benzer olarak BAP ve IAA hormonları besi ortamında birlikte bulunduğu durumlarda BAP konsantrasyonu IAA (veya başka bir oksin hormonu) konsantrasyonundan yüksek ise sürgün oluşumunu teşvik ettiği bildirilmiştir (Osman ve ark., 2010; Jan ve ark., 2015). Oluşan kalluslardan bitki oluşumu bakımından ise en yüksek oran $0.5 \mathrm{mg} \mathrm{l}^{-1}$ BAP $+0.1 \mathrm{mg} \mathrm{l}^{-1}$ IAA içeren ortamdan sağlanmış (\%340) olması da yine bu sonuçları destekler niteliktedir. Benzer şekilde Jan ve ark. (2015) yapmış oldukları çalışmada en yüksek direk sürgün rejenerasyonunu birincil yaprak segmentlerinden $1 \mathrm{mg} \mathrm{l}^{-1}$ NAA ve $3 \mathrm{mg} \mathrm{l}^{-1}$ BAP içeren MS besi ortamından; en yüksek oranda indirek sürgün rejenerasyonunu birincil yaprak segmentlerinden $0.5 \mathrm{mg} \mathrm{I}^{-1}$ IAA ve $3 \mathrm{mg} \mathrm{I}^{-1}$ BAP içeren MS besi ortamından elde ettiklerini rapor etmişlerdir.

Namitha ve Negi (2013) sürgün rejenerasyon yeteneğinin çoktan aza hipokotiller, kotiledon, yaprak diskleri şeklinde izlediğini bildirmiştir ancak araştırmacılar meristem kültürünü araştırmalarına dahil etmemişlerdir. Yapılan birçok çalışmada da in vitro rejenerasyon bakımından hipoktil eksplantları ile yaprak eksplantları kıyaslanmış ve hipokotil eksplantlarının daha iyi rejenerasyon yeteneğine sahip olduğu bildirilmiştir (Mamidala ve Nanna, 2011; Chaudhry ve ark., 2010). In vitro çalışmlarda meristematik dokuların özellikle genetik stabilitenin korunması veya direk organogenesis istendiği durumlarda ön plana çıktığı domateste ve diğer birçok bitkide rapor edilmiştir (Koenig ve ark., 2009; Wamaitha ve ark., 2010; Gerszberg ve ark., 2015).

\section{SONUÇ}

Bu çalışmada bitki büyüme hormonlarından İndol-3-Asetik Asit (oksin) ve 6-benzyl amino pürin (Sitokinin) hormonlarının domates meristemlerinin gelişimleri üzerine etkileri araştııımıştır. Çalışmada hiçbir hormon kullanılmayan yalın ortam direk rejenerasyon bakımından en iyi sonucu verirken (\%100), kallus oluşumu bakımından ise $0.5 \mathrm{mg} / \mathrm{l} \mathrm{BAP}+0.1 \mathrm{mg} / \mathrm{I}$ IAA içeren ortam en iyi sonucu (\%100) vermiştir. Hiç kuşkusuz bu sonuçlar üzerinde kullanılan besi ortamının içeriği, hormon ve diğer kimyasal büyüme faktörleri, genotip ve diğer fiziksel faktörler de etkili olmaktadır. Ancak bu çalışmada kullanılan materyal ve uygulanan yöntem itibari ile domateste meristem kültürü uygulamalarında direk orgonagenesis için hormon içermeyen ortamların tercih edilmesi, kallus oluşumu için ise IAA ve BAP hormonlarının birlikte bulunduğu ve özellikle IAA konsantrasyonunun yüksek olduğu besi ortamlarının tercih edilmesinin isabetli olacağını söyleyebiliriz.

\section{ÇIKAR ÇATIŞMASI}

Yazarlar arasında herhangi bir çıkar çatışması yoktur.

\section{YAZAR KATKISI}

Hüseyin Uysal çalışmanın planlanması, bazı laboratuvar çalışmaları ve makalenin yazımını gerçekleştirmiştir. Laboratuvar çalışmasının önemli bir kısmı ise diğer yazarlar tarafından gerçekleştirilmiştir.

\section{TEŞEKKÜR}

Bu çalışma TÜBiTAK tarafından 2209A projeleri kapsamında desteklenmiştir. Vermiş olduğu maddi destekten dolayı TÜBiTAK'a ve çalışmada bizlere sera imkanı sunan değerli hocamız Prof. Dr. M. Nedim DOĞAN'a teşekkür ederiz.

\section{KAYNAKLAR}

Ajenifujah-Solebo, S. O. A., Isu, N. A., Olorode, O., Ingelbrecht, I., \& Abiade, O. O. (2012). Tissue culture regeneration of three Nigerian cultivars of tomatoes. African Journal of Plant Science, 14, 370-375.

Al-Remi, F., Arvas, Y. E., Durmuş, M., \& Kaya, Y., (2018). Domates bitkisi ve in vitro mikro çoğaltımı. Journal of Engineering Technology and Applied Sciences, 3(1), 57-73.

Bai, Y., \& Lindhout, P. (2007). Domestication and breeding of tomatoes: what have we gained and what can we gain in the future?, Annals of Botany, 100(5), 1085-1094. 
Balachandar, R., \& Rao, M. V. (2004). Plant regeneration from leaf and stem explants of Solanum trilobatum L. Current Science, 86(11), 1478-1480.

Chaudhry, Z., Abbas, S., Yasmin, A., Rashid, H., Ahmed, H., \& Anjum, M. A. (2010). Tissue culture studies in tomato (Lycopersicon esculentum) Var. Moneymaker. Pakistan Journal of Botany, 42(1), 155-163.

Çevik, B., \& Akçura, N. (2011). Batı Akdeniz Bölgesi domates üretim alanlarında domates kloroz virüsü (ToCV) 'nün tespiti ve moleküler karakterizasyonu. Türkiye IV. Bitki Koruma Kongresi, Kahramanmaraş,

Devi, M., Dhaliwal, M. S., Kaur, A., \& Gosal, S. S. (2008). Effect of growth regulators on in vitro morphogenetic response of tomato. Indian Journal of Biotechnology, 7, 526-530.

Gerszberg, A., Hnatuszko-Konka, K., Kowalczyk, T., \& Kononowicz, A. K. (2015). Tomato (Solanum lycopersicum L.) in the service of biotechnology. Plant Cell, Tissue and Organ Culture, 120, 881-902.

Hatipoğlu, R. (2012). Bitki Biyoteknolojisi. Ders Kitabı, Çukurova Üviversitesi, Ziraat Fakültesi, Tarla Bitkileri Bölümü, No:176, Adana.

Jan, S. A., Shah, H., Ali, S., \& Ali, G. M. (2015). The effect of plant growth regulators on callus induction and somatic embryogenesis of hybrid tomato. Pakistan Journal of Botany, 47(5), 1671-1677.

Koenig, D., Bayer, E., Kang, J., Kuhlemeier, C., \& Sinha, N. (2009). Auxin patterns Solanum lycopersicum leaf morphogenesis. Development, 136, 2997-3006.

Mamidala, P., \& Nanna, R. S. (2011). Effect of genotype, explant source and medium on in vitro regeneration of tomato. International Journal of Genetics and Molecular Biology, 3(3), 45-50.

Namitha, K. K., \& Negi, P. (2013). Morphogenetic potential of tomato (Lycopersicon esculentum) cv. Arka Ahuti to plant growth regulators. Notulae Scientia Biologicae, 2, 220-225.

Oğuz, A. (2010). Bazı yerel domates genotiplerinde farklı yöntemler kullanarak, Domates Lekeli Solgunluk Virüsü (Tomato spotted wilt virus=TSWV)'ne dayanıklılığın ve genetik varyasyonun araştırılması. Ankara Üniversitesi, Fen Bilimleri Enstitüsü, Doktora Tezi, Ankara.

Osman, M. G., Elhadi, E. A., \& Khalafalla, M. M. (2010). Callus formation and organogenesis of tomato (Lycopersicon esculentum Mill, CV Omdurman) induced by thidiazuron. African Journal of Biotechnology, 9(28), 4407-4413.

Öztunç, H. (2010). Antalya illinde domates yetiştiriciliği yapılan seralarda Domates Kloroz Virüsü (ToCV)'nün moleküler yöntemlerle tanılanması, Bitirme Tezi, Süleyman Demirel Üniversitesi Ziraat Fakültesi, Bitki Koruma Bölümü, Isparta.

Raiola, A., Rigano, M. M., Calafiore, R., Frusciante L., \& Barone, A. (2014). Enhancing the health-promoting effects of tomato fruit for biofortified food. Mediators of inflammation. Mediators of Inflammation, 139873.

Sakallı, N. (2018). Bazı Domates genlerinin Kloroz Virüsü (Tomato chlorosis virüs. Tocy) enfeksiyonu sırasında ekspresyonlarının incelenmesi, Süleyman Demirel Üniversitesi Fen Bilimleri Enstitüsü, Yüksek Lisans Tezi, Isparta.

Spooner, D. M., Peralta, I. E., \& Knaap, S. (2005). Comparison of AFLPs with other markers for phylogenetic inference in wild tomatoes, [Solanum L. section Lycopersico (Mill.)Wettst.]. Taxon, 54, 43-61.

TÜiK. (2020). Sebze ürünleri üretim miktarları. https://data.tuik.gov.tr/Bulten/Index?p=Bitkisel-Uretim-Istatistikleri-201930685. Erişim tarihi: 07 Şubat 2020.

Wamaitha, M. J., Suwa, K., Fukuda, K., Mii, M., Daimon, H., \& Mishiba K (2010). Thidiazuron-induced rapid shoot regeneration via embryo-like structure formation from shoot tip-derived callus culture of sugarcane. Plant Biotechnology, 27(4), 365368.

Wu, Z., Sun, S., Wang, F., \& Guo, D., (2011). Establishment of regeneration and transformation system of Lycopersicon esculentum MicroTom. British Biotechnology Journal, 1(3), 53-60.

Zengin, S. (2016). Moleküler markör yardımlı seleksiyon ile viral (Domates Sarı Yaprak Kıvırcıklık Virüsü, Domates Lekeli Solgunluk Virüsü) fungal (Kök ve Kök Boğazı Çürüklügü) hastalıklara ve nematoda (Meloidogyne incognital) dayanıklı domates hastalıklarının geliştirilmesi. Doktora Tezi, Ege Üniversitesi Fen Bilimleri Enstitüsü, Bornova, İzmir. 